\section{ADSORPTION OF CESIUM FROM AQUEOUS SOLUTION USING CHITOSAN BEADS}

\author{
Nor Asikin Awang, Wan Norharyati Wan Salleh*, Mohamad \\ Fakrudin Mustakim Alisah, Ahmad Fauzi Ismail, Nurafiqah \\ Rosmana, Norhaniza Yusof
}

School of Chemical and Energy Engineering, Faculty of Engineering, Universiti Teknologi Malaysia, 81310 UTM Johor Bahru, Malaysia
Article history

Received

23 August 2017

Received in revised form

9 December 2018

Accepted

I January 2019

Published online

18 February 2019

${ }^{*}$ Corresponding author hayati@petroleum.utm.my

\section{Graphical abstract}

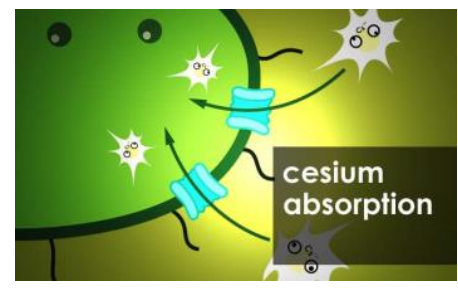

\begin{abstract}
Due to rapid population growth, technological advancement and industrial revolution, the rate of generated waste effluents has become a grave concern. Cesium, which possesses high fission yield, is generally transferred into liquid wastes, especially those emanated from nuclear power plants, reprocessing of spent fuels, nuclear weapon testing, and radionuclides production facilities for medical applications. Radiocesium (137Cs) is one of the hazardous radionuclides which have adverse effects on human health and the environment. Thus, from a health point of view, the removal of cesium from wastewater is imperative. Several techniques have been introduced as solution, and recently, adsorption has been gaining increasing attention among the scientific community owing to a number of reasons. Hence, this research presents an experimental work on sorption of cesium from wastewaters. In this study, chitosan was used as an adsorbent. The effects of several critical parameters, namely contact time, initial concentration, and absorbent dosage on the absorbent performance were investigated. From the findings, the optimum condition for the adsorption of cesium was optimized at $\mathrm{pH} 1$ at $300 \mathrm{mg} / \mathrm{L}$ for 5 hours of contact time. The sorption data fitted well with Freundlich adsorption model, with the value of $\mathrm{R}^{2}=0.9940$, and was best described by pseudo-first-order model with the value of correlation coefficient, $\mathrm{R}^{2}=0.9952$.
\end{abstract}

Keywords: Contaminated water, absorption, chitosan, cesium, absorbent

\begin{abstract}
Abstrak
Disebabkan penambahan penduduk yang pesat, kemajuan teknologi dan revolusi perindustrian, kadar pencemaran sisa yang dihasilkan menjadi kebimbangan. Sesium yang mempunyai hasil perpecahan tinggi biasanya dipindahkan ke dalam air tercemar dimana berpunca daripada loji kuasa nuklear, pemprosesan semula bahan api yang digunakan, ujian senjata nuklear dan pengeluaran radionuklid untuk kemudahan aplikasi perubatan dan lainlain. Radiosesium (137Cs) adalah salah satu daripada radionuklid berbahaya mewujudkan buruk kesan ke atas kesihatan manusia dan alam sekitar. Oleh itu, penyingkiran sesium daripada air tercemar amat penting terutamanya dari segi kesihatan. Beberapa kaedah boleh digunakan tetapi penyelidikan ini menggunakan kaedah penyerapan kerana telah mendapat perhatian lebih oleh masyarakat saintifik kerana beberapa sebab. Oleh itu, kajian ini akan mendiskusi secara keseluruhan tentang penyerapan sesium daripada air tercemar. Oleh itu,chitosan akan digunakan sebagai medium menyerap sesium. Kesan beberapa parameter seperti masa sentuhan, kepekatan awal dan dos penyerapan terhadap kebolehupayaan penyerap telah diambil kira. Keadaan optimum untuk penyerapan cesium dioptimumkan pada pH 1 pada 300 ppm selama 5 jam waktu bersentuhan. Data penyerapan bersesuaian dengan model penyerapan Freundlich dengan nilai $R^{2}=0.9940$ dan paling sesuai digambarkan dengan model pseudo-first-order dengan pekali korelasi, $R^{2}=0.9952$.
\end{abstract}

Kata kunci: Air yang tercemar, penyerapan, chitosan, sesium, bahan penyerap

(c) 2019 Penerbit UTM Press. All rights reserved 


\subsection{INTRODUCTION}

The Fukushima Daiichi Nuclear Power Plant disaster released a huge quantity of hazardous radioactive cesium (Cs) with long half-life into the environment. The so-released radioactive fallout had contaminated nearby raw water sources. Since conventional water works cannot satisfactorily remove dissolved Cs+ from water, the so-produced drinking water had been reported to be contaminated with radionuclide [1]. In addition, most radionuclides in the water rapidly declined to insignificant levels as a result of physical decay, and incorporation in catchment soils during the weeks following the accident. Following the radioactive fallout, a number of possible intervention measures had been introduced to reduce radioactive doses to the public via the surface water pathway. The countermeasures can be grouped into two categories; those aimed at reducing doses from radioactivity in drinking water, and those aimed at reducing doses from consumption of aquatic foodstuffs, principally freshwater fish [2]. In the context of atmospheric fallout of radioactivity in both terrestrial and aquatic systems, it has been shown that doses from terrestrial foodstuffs are, in general, more significant than doses from drinking water and aquatic food stuffs [3]. Table 1 presents a summary of the rank of risks associated with various heavy metals.

Table 1 Ranking of risks associated with various heavy metals [3]

\begin{tabular}{cc}
\hline Relative Priority & Environmental Risk \\
\hline \multirow{2}{*}{ High } & $\mathrm{Cs}$ \\
& $\mathrm{Pb}$ \\
& $\mathrm{Sr}$ \\
\hline \multirow{3}{*}{ Medium } & $\mathrm{Co}$ \\
& $\mathrm{Cu}$ \\
& $\mathrm{Ni}$ \\
& $\mathrm{Al}$ \\
\hline Low & $\mathrm{Fe}$ \\
\hline
\end{tabular}

Humans may be exposed to cesium by breathing, drinking, or eating. Although the level of cesium in the air is generally low, radioactive cesium has been detected at some levels in surface water and in many types of foods [4] after the Fukushima Daiichi Nuclear Power Plant disaster. The amount of cesium in foods and drinks depends on the exposure to radioactive cesium from nuclear power plants, mainly through accidents. As there has been no accident since the Chernobyl disaster in 1986, it is not very likely that people experience health effects that can be related to cesium itself [5]. When contact with radioactive cesium occurs, which is highly unlikely, a person can experience cell damage due to radiation from the cesium particles [6]. Due to this, effects such as nausea, vomiting, diarrhea and bleeding may occur.
Long exposure may cause people to lose consciousness. Coma or even death may follow. The seriousness of the effects depends on the resistance of individuals, and the duration of exposure, as well as the concentration a person is exposed to [7].

Various treatment methods such as chemical precipitation, coagulation-flocculation, reverse osmosis, adsorption, and ultra-filtration have been used to remove heavy metals from contaminated wastewater [8, 9]. Among the methods listed, adsorption has become the most preferred alternative treatment technique for wastewater laden with heavy metals as it is a simple technique which is easy to operate, highly effective for a wide variety of target pollutants, and has a low operating cost. Basically, adsorption is a mass transfer process by which a substance is transferred from the liquid phase to the surface of a solid, and becomes bound by physical and/or chemical interactions. Figure 1 presents a summary on the adsorption materials and factor that effect the adsorption process.

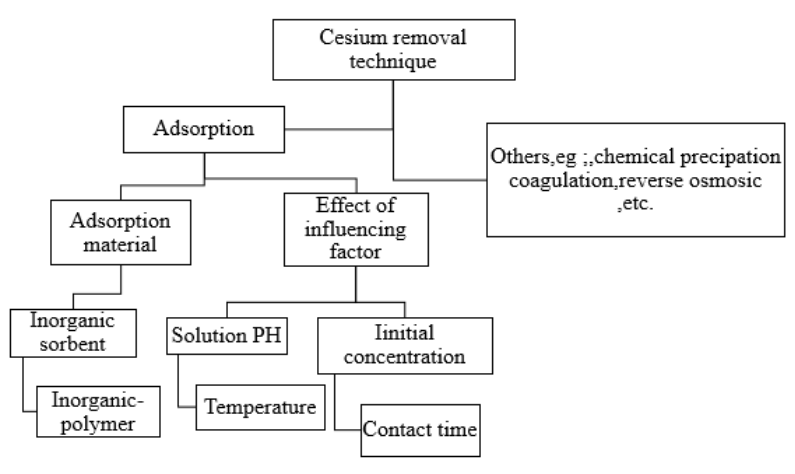

Figure 1 Adsorption materials and adsorption factors [8]

Several factors that influence the effectiveness of the removal of cesium from solutions depend on the adsorbents themselves. Various techniques have been proposed including the utilization of many different kinds of adsorbents. Previously, most of the adsorbents are carbon-based materials. However, due to cost concerns, the use of these materials presents some limitations for it to be continuously used in cesium removal. Thus, the researchers narrowly focused on the use of bio-sorbents. Among various bio-sorbents, chitosan is the second most abundant natural biopolymers after cellulose [9]. Chitosan has attracted interest among researchers, as it is an effective scavenger for heavy metals. Due to its adaptability, chitosan is applied to biocompatible, biodegradable, and nontoxic materials. Chitosan is obtained from chitin. It is a linear polymer which mainly consists of $\beta$ (1-4)-2-acetamido-2-deoxy-D-glucopyranose units and low amount $\beta$-(1-4)-2-amino-2-deoxy-D-glucopyranose residues. Generally, chitin can be found in the exoskeleton of crustaceans, in fungal cell walls, and other biological materials. The adsorption capacity of 
chitosan for some metals is available in the literature. In this study, chitosan-based absorption was performed, followed by absorption method. Batch experiments were carried out for the adsorption of cesium [9, 10]. Primary parameters, namely contact time, initial concentration, and absorbed dosage were investigated.

\subsection{METHODOLOGY}

\subsection{Materials}

Chitosan with $90 \%$ deacetylation degree, $\mathrm{CsNO}_{3}$ and all other chemicals used in this research were of analytical grade and supplied by Qrec, MERCK, and Sigma Aldrich (M) Sdn Bhd, respectively.

\subsection{Preparation of Chitosan Beads}

$4 \mathrm{~g}$ Chitosan was completely dissolved in $100 \mathrm{~mL}$ of $3 \%$ $(\mathrm{v} / \mathrm{v})$ acetic acid in pure water overnight at room temperature. Fe (III) and Fe (II) (0.02 mol: 0.01 mol) was dissolved into the chitosan solution. The mixture was stirred for 2 hours, and then left for half an hour. The mixed solution was then added into $500 \mathrm{~mL}$ of $10 \mathrm{~g}$ of $\mathrm{NaOH}$ solution (containing $7.5 \mathrm{~mL}$ ethylacetate), dropwise to form the beads, and stirred continuously for 3 hours to solidify the chitosan beads. The beads were then separated from the $\mathrm{NaOH}$ solution, and washed with distilled water until it became neutral. The chitosan beads were later dried at $60 \circ \mathrm{C}$ for 24 hours [11].

\subsection{Characterization Method}

Scanning Electron Microscopy (SEM) was used to characterize the structure of the chitosan beads before and after adsorption process. Inductively Coupled Plasma Mass Spectrometry or ICP-MS was used to determine the cesium ion concentration in the sample solution.

\subsection{Cesium Adsorption Studies}

Batch experiments were conducted in a temperaturecontrolled shaker. The speed of the shaker was set to $150 \mathrm{rpm}$ for all experiments, and at $30 \circ \mathrm{C}$. In order to optimize Cs+ removal condition, the effect of contact time, initial concentration, and absorbent dosage were investigated. For batch adsorption experiments, $50 \mathrm{ml}$ of $5 \% \mathrm{HNO}_{3}$ and $\mathrm{Cs}+$ solution was mixed with 30 mg adsorbent with different initial concentrations (50$300 \mathrm{mg} / \mathrm{L}$ ) in $100 \mathrm{~mL}$ glass bottles. For the adsorption isotherm experiments, the initial $\mathrm{pH}$ was 6, while the initial Cs+ concentration was varied from 50 to 300 $\mathrm{mg} / \mathrm{L}$ at $30 \circ \mathrm{C}$. After equilibration, the samples were separated and analyzed for their Cs+ content using Inductively Coupled Plasma Mass Spectrometry (ICPMS), using the following equation:

$$
\mathrm{qe}_{\mathrm{e}}=\left(\mathrm{C}_{0}-\mathrm{Ce}_{\mathrm{e}}\right) \mathrm{V} / \mathrm{W}
$$

where $q_{e}(\mathrm{mg} / \mathrm{g})$ is the equilibrium adsorption capacity, $\mathrm{C}_{0}$ and $\mathrm{Ce}$ are the initial and equilibrium concentrations (mg/L) of Cst, $V(L)$ is the volume of the Cs+ solution and $W(g)$ is the weight of the dried adsorbent.

The effect of adsorbent dosage on adsorption performance was examined by operating various adsorbent dosages $(0.6,2.3,4.8,7.5 \mathrm{~g} / \mathrm{L})$ to $50 \mathrm{~mL}$ of the solution containing $100 \mathrm{mg} / \mathrm{L} \mathrm{Cs}+$ at $298.15 \mathrm{~K}$.

\subsection{RESULTS AND DISCUSSION}

\subsection{Characterization of Chitosan Beads}

The morphological structure of chitosan bead was analyzed using Scanning Electron Microscope (SEM) as shown in Figure 2. It was observed that the chitosan had porous and fibril structures. The bead had an oval shape of about $1 \mathrm{~mm} \times 1.3 \mathrm{~mm}$ before absorption, and became $1.2 \mathrm{~mm} \times 1.5 \mathrm{~mm}$ after absorption. The EDS analysis of chitosan showed the presence of $\mathrm{C}, \mathrm{O}, \mathrm{N}$ and $\mathrm{Fe}$ [12].

\subsection{Effect of Initial Cs+ Concentration}

The effects of initial Cst ions concentrations on adsorption performance of chitosan are shown in Figure 3. In these experiments, operational parameters were kept constant (Contact time, $t=2$ hours; Adsorbent dosage, weight per volume, $w / \mathrm{v}=0.6 \mathrm{~g} / \mathrm{L}$; $\mathrm{pH}=6$; shaking rate $=150 \mathrm{rpm}$ ). It was observed that the heavy metal ion removal increased with the increase of initial Cs+ concentration. This was because, with the existence of more $\mathrm{Cs}+$ in the solution, more active sites of chitosan beads were involved in the adsorption process.
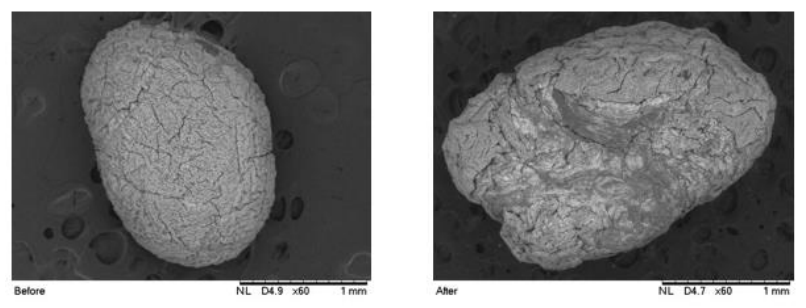

Figure 2 SEM of chitosan bead before and after absorption of Cs+

The higher ions concentration enhanced the mass transfer driving force, and increased the metal ions uptake capacity at equilibrium. In addition, with the increase of the metal ions concentration, the number of collisions between metal ions and adsorbent increased, which enhanced the adsorption process [13]. The optimum initial concentration of $300 \mathrm{mg} / \mathrm{L}$ was chosen to be used in the next experiment. 


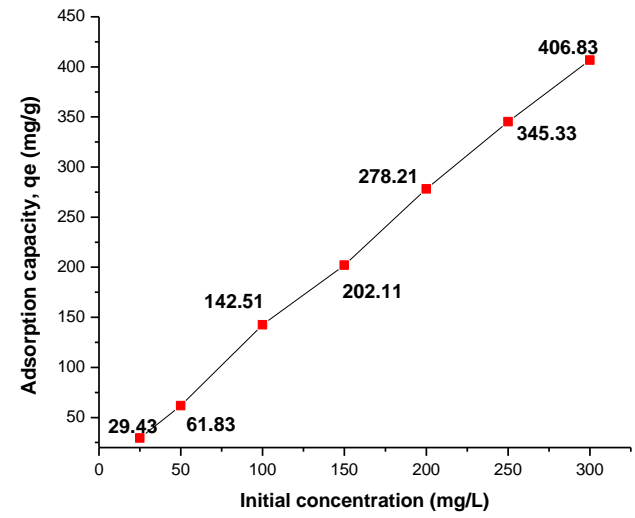

Figure 3 Effect of initial concentration on the adsorption of Cst by chitosan beads (contact time,t $=2 \mathrm{~h}$; adsorbent dosage, $\mathrm{w} / \mathrm{v}=0.6 \mathrm{~g} / \mathrm{L} ; \mathrm{pH}=6$; shaking rate $=150 \mathrm{rpm}$ )

\subsection{Effect of Contact Time}

Contact time is an important parameter because this factor determines the adsorption kinetics of an absorbent at a given initial concentration. The effect of contact time on the ions adsorption by chitosan was investigated for 1-5 hours. Figure 4 shows that adsorption of $\mathrm{Cs}+$ ion increased with the increase of contact time. Within the first 2 hours, rapid adsorption of $\mathrm{Cs}^{+}$was observed. The adsorption behaviour slowed down at a later stage due to the repulsive forces between the solute molecules of the solid and bulk phase, so the remaining vacant surface sites might have been difficult to occupy [14]. The results demonstrated that the rate of absorbent to absorb the ion was very high within 2 hours of contact time. Thus, the adsorption capacity of $158.83 \mathrm{mg} / \mathrm{g}$ with $92 \%$ of ion removal was chosen as the optimum condition.

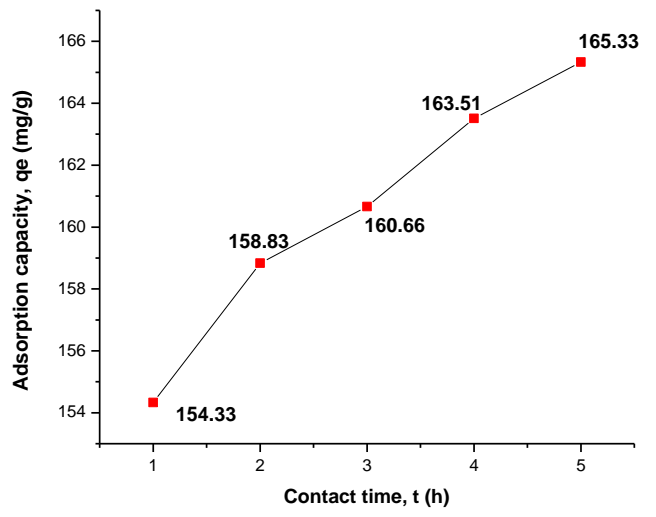

Figure 4 Effect of contact time on the adsorption of Cs+ by chitosan beads (initial concentration $=300 \mathrm{mg} / \mathrm{L}$; adsorbent dosage, $\mathrm{w} / \mathrm{v}=0.6 \mathrm{~g} / \mathrm{L} ; \mathrm{pH}=6$; shaking; rate = $150 \mathrm{rpm}$ )

\subsection{Effect of Adsorbent Dosage}

Experiments were carried out with initial Cs+ concentration of $300 \mathrm{mg} / \mathrm{L}$, and adsorbent dosage varied from $0.6 \mathrm{~g} / \mathrm{L}$ to $7.5 \mathrm{~g} / \mathrm{L}$, as shown in Figure 5 . It was observed that removal efficiency optimized at 0.6 $\mathrm{g} / \mathrm{L}$ of absorbent, with adsorption capacity value of $161.83 \mathrm{mg} / \mathrm{g}$. However, the adsorption capacity of Cs+ ions decreased when the adsorbent dosage was increased, due to the maximum capability of the beads to absorb the ion. In addition, the reduction in adsorption capacity might have been due to the saturation of the adsorption active sites, which were involved in the adsorption process [15].

\subsection{Adsorption Isotherms Studies}

Data for the uptake of Cst at different concentrations were processed in accordance with the linearized form of Langmuir and Freundlich adsorption isotherms. Both isotherms relate to the amount of solute adsorbed at equilibrium per unit weight of adsorbent. The Langmuir isotherm corresponded to the monolayer adsorption of $\mathrm{Cs}+$ on the surface of chitosan sites.

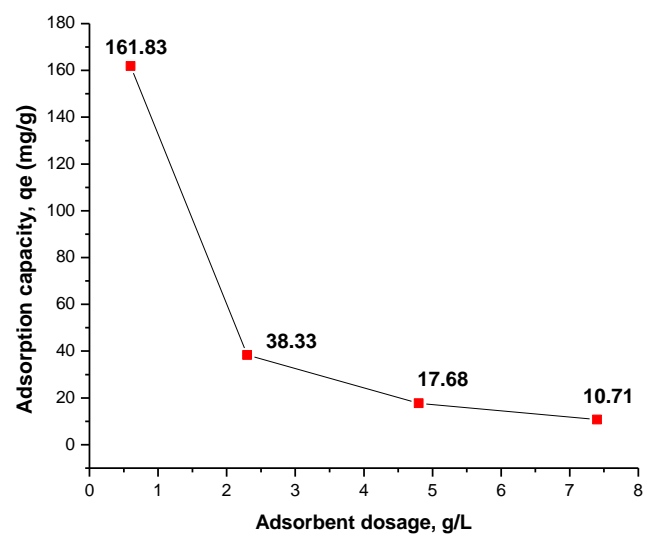

Figure 5 Effect of adsorbent dosage on the uptake of Cs+ by chitosan beads (initial concentration $=300 \mathrm{mg} / \mathrm{L}$; contact time, $t=2 \mathrm{~h} ; \mathrm{pH}=6$; shaking rate $=150 \mathrm{rpm}$ )

The linear form of the Langmuir adsorption isotherm is shown in Equation (1) [16]:

$\mathrm{Ce}_{\mathrm{e}} / \mathrm{qe}_{\mathrm{e}}=\left(1 / \mathrm{Q}_{0} b\right)+\left(1 / \mathrm{Q}_{0}\right) \mathrm{Ce}_{\mathrm{e}}$

where Ce represents the equilibrium concentration of Cs+ $(\mathrm{mg} / \mathrm{L})$, and qe corresponds to the amount of Cs+ uptake per gram at equilibrium $(\mathrm{mg} / \mathrm{g})$. Meanwhile, Q0 $(\mathrm{mg} / \mathrm{g})$ and $b(\mathrm{~L} / \mathrm{mg})$ are the Langmuir constants which stand for adsorption capacity and rate of adsorption. The values of $\mathrm{QO}$ and $\mathrm{b}$ can be obtained by plotting the graph of $\mathrm{C}_{e} / \mathrm{q}_{e}$ against $\mathrm{C}_{\mathrm{e}}$. Freundlich adsorption isotherm proposes multilayer adsorption of adsorbate onto the adsorbent. The Freundlich adsorption isotherm can be presented in linear form as shown in Equation (2): 
$\log q_{e}=\log _{10}\left(K_{f}\right)+(1 / n) \log _{10}\left(C_{e}\right)$

where ge is the amount of Cst adsorbed at equilibrium $(\mathrm{mg} / \mathrm{g})$ and $\mathrm{Ce}$ is the equilibrium concentration of $\mathrm{Cs}+$ at equilibrium (mg/L). $\mathrm{K}_{f}$ and $\mathrm{n}$ are Freundlich constants for adsorption capacity $(\mathrm{mg} / \mathrm{g})$ and adsorption intensity, respectively. From the slope and intercept of the graph log qe versus $\log C_{e}$, the value of $K_{f}$ and $n$ were obtained. Figure 6 shows the linear plot of $\mathrm{C}_{\mathrm{e}} / \mathrm{q}_{\mathrm{e}}$ versus $\mathrm{Ce}$ and graph of log qe against $\log \mathrm{C}_{e}$ as shown in Figure 7 . Based on the value of correlation coefficient, $\mathrm{R}^{2}$, the Freundlich model with the value of $r^{2}=0.9940$ was found to fit better than Langmuir isotherm model with the value of $r^{2}=0.4270$. This indicates that the adsorption behaviour of $\mathrm{Cs}+$ onto chitosan was a multilayer adsorption.

\subsection{Adsorption Kinetic Studies}

In the present study, pseudo-first-order and pseudosecond-order models were implemented to analyze the adsorption behaviour of Cst as a function of time. Both models were applied using Equations (3) and (4), respectively.

$\log \left(q_{e}-q_{t}\right)=\log q_{e}-\left(k_{1} t / 2.303\right)$

where ge is the amount of adsorbed Cst at equilibrium time $(\mathrm{mg} / \mathrm{g}), \mathrm{q}^{+}$is the amount of Cs+ adsorbed at time $t(\mathrm{mg} / \mathrm{g})$, and $\mathrm{k}_{1}$ is the rate constant of pseudo-first-order $(1 / \mathrm{h})$.

$\left(t / q_{t}\right)=\left(1 / k_{2} q_{e}\right)^{2}+\left(t / q_{e}\right)$

where $k_{2}$ indicates the rate constant of pseudosecond-order kinetic model ( $\mathrm{g} / \mathrm{mg} \mathrm{h})$. The relationship of the adsorbate with the adsorbent can be briefly studied by plotting log $\left(\mathrm{q}_{\mathrm{e}}-\mathrm{q}_{t}\right)$ against $t$ for pseudo-firstorder model, and t/qt versus $t$ for pseudo-secondorder kinetic model [17]. The experimental data fitted the linear form by using Equations (3) and (4), and the results are shown in Figure 8 and Figure 9, respectively. Based on the value of correlation of coefficient, $R^{2}$, the data best fitted, and agreed well with pseudo-firstorder model with the value of $R^{2}=0.9952$, compared to pseudo-second-order model with the value of $R^{2}=$ 0.7616 . These results showed that the adsorption behaviour of $\mathrm{Cs}+$ onto chitosan followed the pseudofirst-order, indicating that the adsorption was based on physical adsorption.

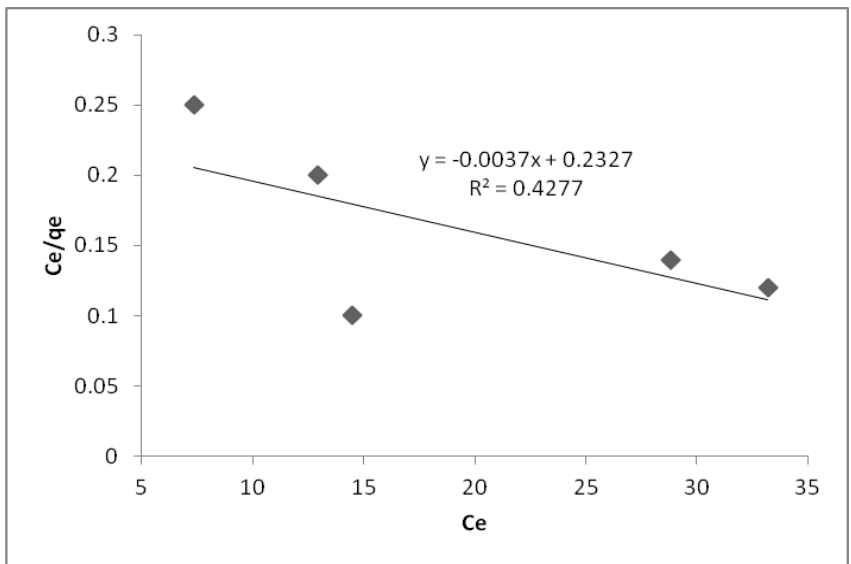

Figure 6 Langmuir plot for adsorption of Cs+ onto chitosan

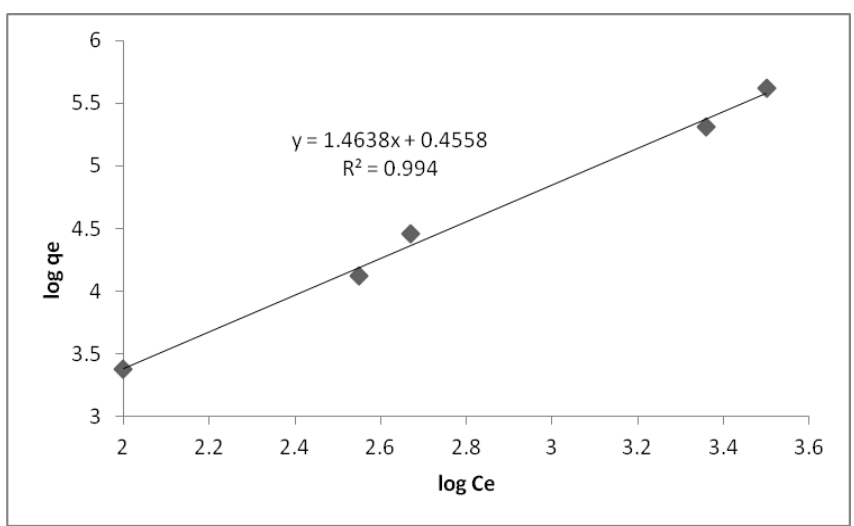

Figure 7 Freundlich plot for adsorption of Cs+ onto chitosan

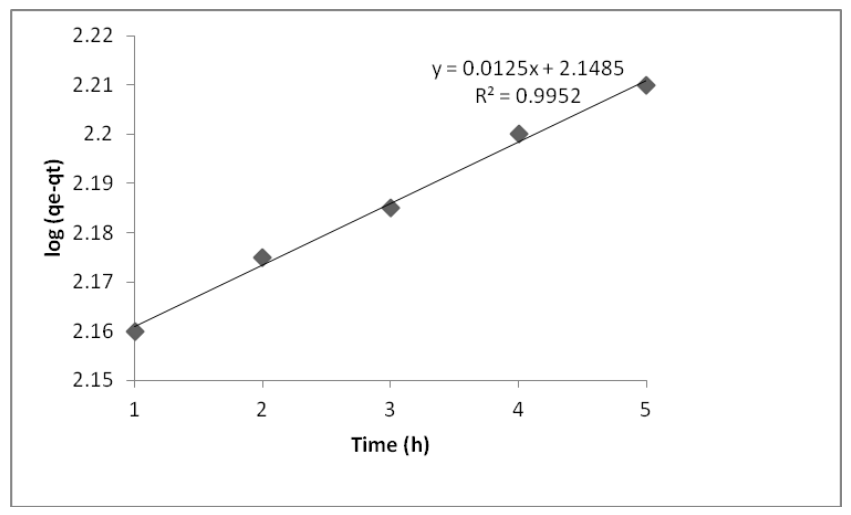

Figure 8 Kinetic plot of pseudo-first-order of the adsorption of Cs+ onto chitosan 


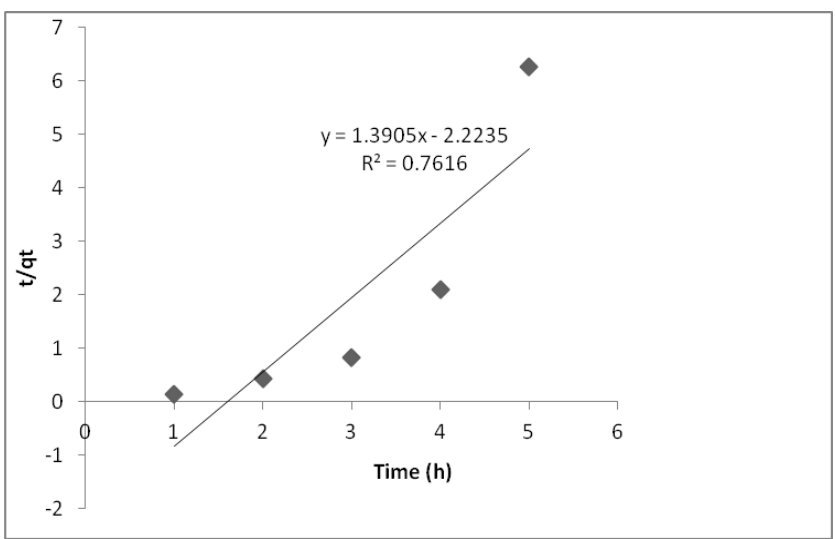

Figure 9 Kinetic plot of pseudo-second-order of the adsorption of $\mathrm{Cs}+$ onto chitosan

\subsection{CONCLUSION}

Adsorption has become an important method to remove heavy metal ions and radionuclides from wastewater. In this study, chitosan beads were prepared and applied to remove Cs+ from aqueous solution. The result indicated that the adsorption equilibrium was reached within 2 hours, with $0.6 \mathrm{~g} / \mathrm{L}$ absorbent dosage and an initial concentration of $300 \mathrm{mg} / \mathrm{L}$. The adsorption data fully fitted the Freundlich isotherm model, and followed the pseudofirst-order kinetic model. Chitosan beads have the potential to be an alternative absorbent for removing radionuclides from aqueous solutions.

\section{Acknowledgement}

The authors would like to thank the Ministry of Education (R.J090301.7846.4J186) and Universiti Teknologi Malaysia (Q.J130000.2546.18H97) for the financial support provided in completing this work.

\section{References}

[1] Matsuda, N., Mikami, S., Sato, T., and Saito, K. 2013. Measurements of Air Dose Rates in and Around Houses in the Fukushima Prefecture in Japan after the Fukushima Accident. Journal of Environmental Radioactivity. 166(Part 3): 427-435.

[2] Hirose, K., Amano, H., Baxter, M. S., Chaykovskaya, E., Chumichev, V. B., Hong, G. H., Veletova, N. K. 1999.
Anthropogenic Radionuclides in Seawater in the East Sea/Japan Sea: Results of the First-stage Japanese-KoreanRussian Expedition. Journal of Environmental Radioactivity. 43(1): 1-13.

[3] Marzo, G. A. 2014. Atmospheric Transport and Deposition of Radionuclides Released After the Fukushima Dai-Chi Accident and Resulting Effective Dose. Atmospheric Environment. 94: 709-722.

[4] Yamashita, S., and Suzuki, S. 2013. Risk of Thyroid Cancer after the Fukushima Nuclear Power Plant Accident. Respiratory Investigation. 51 (3): 128-133.

[5] Yang, M., Jawitz, J. W., and Lee, M. 2015. Uranium and Cesium Accumulation in Bean (Phaseolus vulgaris L. var. vulgaris) and its Potential for Uranium Rhizofiltration. Journal of Environmental Radioactivity. 140: 42-49.

[6] Ramola, R. C., Yadav, M., and Gusain, G. S. 2014 Distribution of Natural Radionuclide along Main Central Thrust in Garhwal Himalaya. Journal of Radiation Research and Applied Sciences. 7(4): 614-619.

[7] McKim Jr., J. M., Baas, H., Rice, G. P., Willoughby Sr, J. A., Weiner, M. L., and Blakemore, W. 2016. Effects of Carrageenan on Cell Permeability, Cytotoxicity, and Cytokine Gene Expression in Human. 13-16.

[8] Barakat, M. A. 2011 . New Trends in Removing Heavy Metals from Industrial Wastewater. Arabian Journal of Chemistry. 4(4): 361-377.

[9] Lan, T., Feng, Y., Liao, J., Li, X., Ding, C., Zhang, D., and Liu, N. 2014. Biosorption Behavior and Mechanism of Cesium137 on Rhodosporidium Fluviale Strain UA2 Isolated from Cesium Solution. Journal of Environmental Radioactivity. 134: 6-13.

[10] Li, A., Lin, R., Lin, C., He, B., Zheng, T., Lu, L., and Cao, Y. 2016. An Environment-friendly and Multi-functional Absorbent from Chitosan for Organic Pollutants and Heavy Metal lon. Carbohydrate Polymers. 148: 272-280 .

[11] Chen, C., and Wang, J. L. 2008. Removal of Pb2+, Ag+, Cs+ $\mathrm{Sr} 2+$ from Aqueous Solution by Brewery's Waste Biomass. Journal of Hazardous Materials. 151: 65-70.

[12] Zhou, L. M., XU, J. P., Liang, X. Z., and Liu, Z. R. 2010. Adsorption of Platinum(IV)and Palladium(II) from Aquesou Solution by Magnetic Cross-linking Chitosannanoparticles Modified with Ethylenediamine. Journal of Hazardous Materials. 182: 518-524.

[13] Bai, S. R., and Abraham, T. E. 1998. Biosorption of Cs(VI) from Aqueous Solution by Rhizopusnigricans. Journal of Scientific \& Industrial Research. 57: 806-816.

[14] Viswanadham, M., Sriramula, N., and Adharvana, M. C. 2000. Removal of $\mathrm{Zn}$ (II) and Ni(II) lons by Using a Biopolymer Chitin. Indian Journal Environmental Protection. 20: 515-520.

[15] Kumar, M., Tripathi, B. P., and Shahi, V. K. 2009. Crosslinked Chitosan/polyvinyl Alcohol Blend Beads for Removal and Recovery of Cd(II) Wastewater. Journal of Hazardous Materials. 172: 1041-10.

[16] Ali, A. 2017. Removal of Mn (II) from Water by using Chemically Modified Banana Peels as Efficient Adsorbent. Journal of Environmental Nanotechnology, Monitoring \& Management. 7: 57-63.

[17] Anandkumar, J., and Mandal, B. 2009. Removal of $\mathrm{Cr}(\mathrm{VI})$ from Aqueous Solution using Bael Fruit (Aegle Marmelos Correa) Shell as Adsorbent. Journal of Hazardous Materials. 168: 633-640. 